\title{
Cambuci: a native fruit from the Brazilian Atlantic forest showed nutraceutical characteristics
}

\author{
Tatiane de Oliveira Tokairin ${ }^{1}$, Aline Priscilla Gomes da Silva ${ }^{1}$, Poliana Cristina Spricigo ${ }^{1}$, \\ Severino Matias de Alencar ${ }^{2}$, Angelo Pedro Jacomino ${ }^{3}$
}

Abstract - The Atlantic Forest is recognized as a biome rich in biodiversity. Cambuci trees (Campomanesia phaea) produce fruits that may be consumed as both fresh and processed forms but are still underutilized. The aim of this study was to describe the physicochemical characteristics and bioactive compounds in cambuci fruits from Brazilian Atlantic Forest, located at Natividade da Serra-SP, Brazil. Cambuci fruits of the fifty-nine accessions were characterized according to fresh weight, pulp yield, peel percentage, longitudinal and transversal diameters (LD and TD, respectively), $\mathrm{pH}$, soluble solids content (SSC), titratable acidity (TA), SSC/TA ratio, ascorbic acid, total phenolic compounds content, and antioxidant capacity using the DPPH assay. The soluble solids contents varied from $5.10^{\circ}$ Brix to $11.00^{\circ}$ Brix. The titratable acidity varied from 1.29 to $2.90 \mathrm{~g}$ citric acid $100 \mathrm{~g}^{-1}$. Ascorbic acid content was of 31.12 to $139.38 \mathrm{mg}^{100 \mathrm{~g}^{-1} \text {. Total }}$ phenolic compounds varied from $330.5 \mathrm{mg}$ GAE $100 \mathrm{~g}^{-1}$ to $3,526.04 \mathrm{mg}$ GAE $100 \mathrm{~g}^{-1}$. The antioxidant capacity was of $65.03 \mu \mathrm{mol}$ Trolox g-1 fruit pulp (fresh weight) to $199.78 \mu \mathrm{mol}$ Trolox $\mathrm{g}^{-1}$ fruit pulp (fresh weight), a factor of 6.7 difference between the extremes. These results showed cambuci fruits presented as rich source of ascorbic acid, total phenolic compounds, and with high antioxidant capacity.

Index Terms: Campomanesia phaea, postharvest quality, phenolic compounds, antioxidant capacity.

\section{Cambuci: fruto nativo da Mata Atlântica brasileira contém características nutracêuticas}

\section{Corresponding author: jacomino@usp.br}

Received: September 25, 2017 Accepted : January 19, 2018.

Copyright: All the contents of this journal, except where otherwise noted, is licensed under a Creative Commons Attribution License.

\section{$(\mathrm{cc}) \mathrm{BY}$}

Resumo - A Mata Atlântica é reconhecida como um bioma rico em biodiversidade. Plantas de cambuci (Campomanesia phaea) produzem frutas que podem ser consumidas nas formas frescas e processadas, mas ainda são subutilizadas. O objetivo deste estudo foi descrever as características físico-químicas e os compostos bioativos em frutos de cambuci oriundos da Mata Atlântica brasileira, localizado na cidade de Natividade da Serra-SP, Brasil. Frutos de cambuci de cinquenta e nove acessos foram caracterizados de acordo com o peso fresco, o rendimento da polpa, a porcentagem de casca, os diâmetros longitudinal e transversal (DL e DT, respectivamente), o pH, o teor de sólidos solúveis (TSS), a acidez titulável (AT), a relação TSS/ AT, o ácido ascórbico,os teores de compostos fenólicos totais e a capacidade antioxidante, pelo método de DPPH. Os teores de sólidos solúveis variaram de 5,10 ${ }^{\circ}$ Brix a $11,00{ }^{\circ} \mathrm{Brix}$. A acidez titulável variou de 1,29 a 2,90 g de ácido citrico $100 \mathrm{~g}^{-1}$. O teor de ácido ascórbico foi de $31,12 \mathrm{a}$

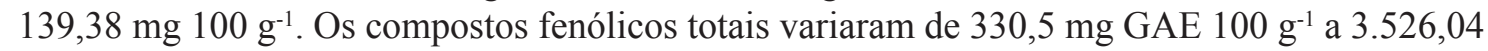
mg GAE $100 \mathrm{~g}^{-1}$. A capacidade antioxidante foi de $65,03 \mu \mathrm{mol}$ Trolox $\mathrm{g}^{-1}$ de polpa de fruta (peso fresco) para 199,78 $\mu \mathrm{mol}$ Trolox $\mathrm{g}^{-1}$ de polpa de fruta (peso fresco), fator de 6.7 de diferença entre os extremos. Estes resultados demonstram que os frutos de cambuci se apresentam como uma fonte rica de ácido ascórbico, de compostos fenólicos totais e com alta capacidade antioxidante. Termos para Indexação: Campomanesia phaea, qualidade pós-colheita, compostos fenólicos, capacidade antioxidante. 
Various species of the Myrtaceae are native of the Brazilian biomes, being that the Atlantic Forest is a biome with many occurrences of species from this botanical family whose fruit is commercially important due the quality of fruits. Some species, such as jabuticaba, guava, and pitanga, are more known, while others such as cambuci require further study, due to their great economic potential.

Cambuci is typical fruit tree from the Atlantic Forest of São Paulo State, Brazil, and it is found near the Coastal Forest (called Serra do Mar, São Paulo). It also occurs in Minas Gerais and Rio de Janeiro States (LORENZI et al., 2006). The fruit has a fleshy and succulent pulp, low seed amount, and an intense and sweet aroma. They are used as flavoring agents and in the preparation of juice, jam and sweets (SANCHES AZEVEDO et al., 2017; VALLILO et al., 2005).

The nutritional characteristics, bioactive compounds, and exotic flavor of cambuci fruits can facilitate their penetration in various market segments. While studies of cambucis are still incipient, these fruits have been reported as important sources of bioactive compounds such as tannins, phenolic compounds and flavonoids, which can control metabolic disorders and obesity (DONADO-PESTANA et al., 2015). The cambuci have remarkable nutritional and therapeutic values, it could be included in the regular consumption of fruits. Therefore, its attract characteristics are growing interest worldwide due to increased human concern in healthy food (SILVA et al., 2014).

Despite their huge commercial potential, cambuci fruit are only distributed in the local and regional markets of the growing regions in the Serra do Mar Coastal Forest in São Paulo State. They are sold as processed homemade products such as frozen pulp, jam, ice cream, and sweets (INSTITUTO AUA, 2017). Most of the cambuci plantations are restricted to home orchards, small properties where the orchards were established from plants multiplied by seed. Plantations are irregular, tree productivity is low, and fruit quality is not standardized, varying widely because of pre- and post-harvest factors such as genetic traits, climate, and cultivation practices. This study aimed to describe the physicochemical characteristics and bioactive compounds from cambuci accessions of the Atlantic Forest - São Paulo State.

Fruit from fifty-nine eight-year-old cambuci accessions were collected from a commercial plantation of non-cloned plants in Natividade da Serra-SP, Brazil $\left(23^{\circ} 31^{\prime} \mathrm{S} \mathrm{e} 45^{\circ} 27^{\prime} \mathrm{W}\right)$. The fruits were manually collected when they naturally abscised. The fruit was then carefully transported to the Postharvest Laboratory of Horticultural Products (LPV-ESALQ - USP) in Piracicaba-SP, Brazil. Ten undamaged and uniformly mature fruit were selected per plant and stored in a cold chamber at $15^{\circ} \mathrm{C}$ and $85 \%$ $\mathrm{RH}$.

Fruit was evaluated based on the following physicochemical properties and bioactive compound measurements: a) Fresh weight of the whole fruit - determined using an analytical balance, results were expressed in grams (g); b) Pulp yield and peel percentage - obtained using the ratios between the weight of the whole fruit weight and those of its parts. The peel was manually removed using a spatula and the seeds were left in the pulp; c) Longitudinal and transverse diameters (LD and RD, respectively) - measured using a digital caliper, results were expressed in millimeters ( $\mathrm{mm})$; d) $\mathrm{pH}$ - measured in liquefied samples using a potentiometer (AOAC, 2012); e) Soluble solids content (SSC) - measured in the pulp using a digital refractometer (Atago Palette PR-101), results were expressed in ${ }^{\circ}$ Brix (AOAC, 2012); f) Titratable acidity (TA) - measured in the pulp, by using the method described in AOAC (2012), results were expressed in $g$ of citric acid per $100 \mathrm{~g}^{-1} ; \mathrm{g}$ ) Ratio - SSC/AT; h) Ascorbic acid (AA)- measured by titration with sodium 2,6-dichlorophenolindophenol in a juice aliquot diluted in oxalic acid at 0.5\% (STROCHECKER; HENNING, 1967), results were expressed in $\mathrm{mg} 100 \mathrm{~g}^{-1}$; i) Total phenolic compounds according to the method recommended by Woisky and Salatino (1998), results were expressed in $\mathrm{mg} 100 \mathrm{~g}^{-1}$ of gallic acid (GAE); j) Antioxidant capacity by DPPH free radical scavenging- measured using the method described in Al-Duais et al. (2009), results were expressed in $\mu \mathrm{mol}$ $\mathrm{g}^{-1}$ of Trolox (fresh weight).

The design was completely randomized with four replications of 10 fruits for each species and year of assessment. Results were analyzed using descriptive statistics including central tendency (mean), standard deviation, and coefficient of variation. Correlations between the analyzed variables were studied to determine degrees of association. Coefficients $>0.70$ were selected (STATSOFT, 2010; SOUNIS, 1975).

The cambuci (Campomanesia phaea) fruit sampled from fifty-nine accessions varied in color from green to the grayish-yellowish green $\left(\mathrm{L}=44.14 \pm 2.78 ;{ }^{\circ} \mathrm{Hue}=\right.$ $107.90 \pm 6.26 ; \mathrm{C}=13.00 \pm 4.00)$, which is characteristic of the species (VALLILO et al., 2005). Color is the first attribute perceived by consumers and is a subjective purchasing decision parameter. It is associated with product freshness and is an important determinant for acceptance of the fruit in the marketplace (WU; SUN, 2013). Physical characteristics such as color, size, and pulp quantity directly influence fruit consumption in native fruits, due intense color, freshness and characteristic taste (LIMA et al., 2016).

The cambuci fruit sampled had an average fresh weight of $42.03 \mathrm{~g}$ (Table 1). Fruit from trees in Natividade da Serra-SP (Brazil) showed a lower average fresh weight than those reported by Vallilo et al. (2005) in 
fruits from trees in Caraguatatuba-SP, Brazil (55.81 g). Despite the geographic proximity of these two regions, different weather conditions during the sampling years might explain the discrepancy in the average weight of the fruit from their cambuci accessions. Furthermore, since cambuci populations consist mainly of trees propagated from seed, genetic diversity might have contributed to the fruit weight differences between these two locals.

Growers from the Serra do Mar Coastal Forest region recommended that fruit weighing $>68 \mathrm{~g}$ be classified as large, while medium fruit weighs between $39 \mathrm{~g}$ and 68 $\mathrm{g}$, and small fruit are those weighing $<39 \mathrm{~g}$. This study found that $37 \%$ of the plants produced small fruits and the remaining $63 \%$ produced medium fruit. Large fruits were not found. The data indicates that this variable did not necessarily correlate with pulp yield in small fruits, and had pulp yields similar to those of larger fruit. Some fruit had the highest pulp yield (93.34\%) and, consequently, the lowest peel percentage $(6.66 \%)$, while other fruits by smaller percentages in the same variables $(80 \%$ and $20 \%$, respectively). Vallilo et al. (2005) obtained pulp yield values $(92.53 \%)$ similar to those found in this study, but found higher peel percentages, varying from $13.90 \%$ to $22.85 \%$. Failure to remove seeds from the pulp might account for this difference. Even though cambuci trees have not been genetically improved by breeding, they still have high pulp yields. Therefore, they show promise in terms of agro-industrial exploitation. The coefficients of variation for the above-mentioned attributes indicate wide ranges in fresh weight and peel percentage $(20.13 \%$ and $28.40 \%$, respectively).

The longitudinal diameter (LD), the transverse diameter (TD), and the LD/TD ratio data showed fruits were slightly flattened $(\mathrm{LD} / \mathrm{TD}<1)$. The longitudinal diameter ranged from 30.85 to $44.37 \mathrm{~mm}$ and transverse diameter from 43.80 to $62.54 \mathrm{~mm}$.

The $\mathrm{pH}$ value of the cambuci fruit pulp was the most stable quality attribute analyzed (ranged from 2.39 to 2.83 and coefficient of variation: $3.39 \%$ ) (Table 2). Soluble solids content (SSC) varied from 5.10 to 11.00 ${ }^{\circ}$ Brix, with a mean of $8.60^{\circ}$ Brix. There was variation in the soluble solid content among the accessions about 6 ${ }^{\circ} \mathrm{Brix}$, it is significant because this parameter is associated with fruit sweetness. Similar results were reported by Sanches (2017) in fruits of the same species harvested at Paraibuna-SP $\left(10,36^{\circ}\right.$ Brix $)$. Bianchini (2016) recorded soluble solids contents between 7.30 and $13.30^{\circ}$ Brix in a study with 58 accessions of cambuci trees in São Bento do Sapucaí - SP. Titratable acidity (TA), which contributes to pleasant fruit flavor, varied from $1.29 \%$ to $2.90 \%$ citric acid, with a mean of $1.93 \%$. These results imply that the acidity in cambuci fruit varies between as do sour passion fruit $(2.78 \%$ citric acid) and 'Pera' oranges $(0.95 \%$ citric acid) (LADANIYA, 2008; MEDEIROS et al., 2009).

The SSC/TA ratio is the best way to evaluate the taste of a fruit and is usually used to evaluate its degree of maturation, being more accurately than either SSC or TA alone (COMIOTTO et al., 2012). The mean was 4.62 and the maximum and minimum values were 8.46 and 2.37 , respectively (Table 2). The SSC/TA in some accessions was 1.8 times above the average and approached the range reported for passion fruit (3.09-4.37) (BRASIL et al., 2016). These fruits can be ideal for the fresh market where sweeter, less acidic fruits are preferred.

For ascorbic acid content were obtained mean of $72.16 \mathrm{mg} 100 \mathrm{~g} \mathrm{~g}^{-1}$, maximum and minimum values of $31.12 \mathrm{mg} 100 \mathrm{~g}^{-1}$ and $139.38 \mathrm{mg} 100 \mathrm{~g} \mathrm{~g}^{-1}$, respectively. Therefore, this parameter is highly variable in this species (Table 2). This data is larger than obtained by Vallilo et al. (2005) and by Silva et al. (2012). They obtained values for cambuci fruit between 12.41 and $18.72 \mathrm{mg} 100 \mathrm{~g}^{-1}$. The high level of ascorbic acid surpasses those found in other Myrtaceae species such as red guava found in other Myrtaceae species such as red guava (80.6 mg $\left.100 \mathrm{~g}^{-1}\right)$ (TACO, 2011). The Brazilian government recommends that adults consume $60 \mathrm{mg}$ vitamin $\mathrm{C}$ per day. It is estimated that cambuci fruit weighing an average of $42.03 \mathrm{~g}$ provide $50.55 \%$ of daily ascorbic acid needs, so cambuci fruit could be an alternative of this bioactive compound for the population.

Total phenolic compounds levels in the cambuci fruit varied from $330.50 \mathrm{mg}$ GAE $100 \mathrm{~g}^{-1}$ to $3,526.04 \mathrm{mg}$ GAE $100 \mathrm{~g}^{-1}$ (Table 2). According to the classification proposed by Vasco et al. (2008), cambuci fruits have a high concentration of phenolic compounds $(>500 \mathrm{mg}$ GAE $\left.100 \mathrm{~g}^{-1}\right)$. We found $1,042.17 \mathrm{mg}$ GAE $100 \mathrm{~g}^{-1}$, which is comparable to that of acerola $(1,063.0 \pm 53.1 \mathrm{mg}$ GAE $100 \mathrm{~g}^{-1}$ (RUFINO et al., 2010). The content of total phenolic in the A56 was three times higher than reported for camu-camu fruits $\left(1,176.0 \pm 14.8 \mathrm{mg}\right.$ GAE $\left.100 \mathrm{~g}^{-1}\right)$ (VASCO et al., 2008). These findings add cambuci fruit as an important source of phenolic compounds as camucamu and berries (DONADO-PESTANA et al., 2015). The interest in phenolic compounds has increased among plant scientists and food industry, triggered by their beneficial health effects, as antioxidant and inflammatory properties (AMBRIZ-PÉREZ et al., 2016).

The antioxidant capacity of cambuci fruit was measured based on their ability to scavenge DPPH free radical. A mean of $65.03 \mu \mathrm{mol}$ Trolox $\mathrm{g}^{-1}$ in the fresh weight was obtained. Antioxidant capacity varied from 29.83 to $199.78 \mu \mathrm{mol}$ Trolox $\mathrm{g}^{-1}$ between evaluated fruits. Genovese et al. (2008) reported an average antioxidant capacity of $7.6 \mu \mathrm{mol}$ Trolox $\mathrm{g}^{-1}$ (FW) obtained from cambuci fruits. Some accessions were greater in antioxidant capacity than blueberries which has a value of $191.8 \mu \mathrm{mol}$ Trolox $\mathrm{g}^{-1}$ in the fresh weight (LUTZ et al., 2015).

There was a significant negative correlation between peel percentage and pulp yield. This finding is expected since these factors are interrelated (Table 3). A 
moderate positive correlation was observed between the parameters that characterize fruit size, which indicates that fruit diameter is directly proportional to fruit height.
A moderate negative correlation between TA and the SSC/TA ratio was observed, which means that acidity is an important and predominant component of cambuci fruit flavor.

Table 1. Physical characteristics of cambuci fruits from 59 accessions of a commercial plantation located in Natividade da Serra-SP, Brazil.

\begin{tabular}{|c|c|c|c|c|c|}
\hline Access & $\begin{array}{l}\text { Fresh weight } \\
(\mathrm{g})\end{array}$ & Yield (\%) & $\begin{array}{l}\text { Peel } \\
(\%)\end{array}$ & $\begin{array}{l}\mathrm{LD} \\
(\mathrm{mm})\end{array}$ & $\begin{array}{c}\mathrm{TD} \\
(\mathrm{mm})\end{array}$ \\
\hline A1 & 42.73 & 88.49 & 11.51 & 31.91 & 50.49 \\
\hline A2 & 46.03 & 84.46 & 15.54 & 38.39 & 52.36 \\
\hline A3 & 41.25 & 80.00 & 20.00 & 37.23 & 51.57 \\
\hline A4 & 34.59 & 87.80 & 12.20 & 35.41 & 49.44 \\
\hline A5 & 41.29 & 87.62 & 12.38 & 35.77 & 56.00 \\
\hline A6 & 37.81 & 89.16 & 10.84 & 39.48 & 49.68 \\
\hline A7 & 32.78 & 88.42 & 11.58 & 36.35 & 46.38 \\
\hline A8 & 29.77 & 87.10 & 12.90 & 36.04 & 45.02 \\
\hline A9 & 35.41 & 86.50 & 13.50 & 35.55 & 53.74 \\
\hline A10 & 32.95 & 85.66 & 14.34 & 32.25 & 48.70 \\
\hline A11 & 51.04 & 91.89 & 8.11 & 37.68 & 60.06 \\
\hline A12 & 49.73 & 89.64 & 10.36 & 38.12 & 53.91 \\
\hline A13 & 44.19 & 93.34 & 6.66 & 36.36 & 52.90 \\
\hline A14 & 39.45 & 90.11 & 9.89 & 34.44 & 51.24 \\
\hline A15 & 36.47 & 90.58 & 9.42 & 34.10 & 51.38 \\
\hline A16 & 26.70 & 83.84 & 16.16 & 30.85 & 43.80 \\
\hline A17 & 56.64 & 91.04 & 8.96 & 41.88 & 57.07 \\
\hline A18 & 29.00 & 86.35 & 13.65 & 30.46 & 45.68 \\
\hline A19 & 47.30 & 90.01 & 9.99 & 41.39 & 57.42 \\
\hline A20 & 57.37 & 90.29 & 9.71 & 38.34 & 55.07 \\
\hline A21 & 41.27 & 83.49 & 16.51 & 37.48 & 53.77 \\
\hline A22 & 49.49 & 91.27 & 8.73 & 44.37 & 58.68 \\
\hline A23 & 32.75 & 88.27 & 11.73 & 35.40 & 48.96 \\
\hline A24 & 52.05 & 91.23 & 8.77 & 40.95 & 56.85 \\
\hline A25 & 43.35 & 80.35 & 19.65 & 36.84 & 56.76 \\
\hline A26 & 33.70 & 86.60 & 13.40 & 35.82 & 51.71 \\
\hline A 27 & 37.44 & 90.31 & 9.69 & 35.23 & 50.42 \\
\hline A28 & 50.30 & 90.78 & 9.22 & 38.35 & 54.15 \\
\hline A29 & 50.33 & 90.97 & 9.03 & 40.29 & 59.85 \\
\hline A30 & 45.03 & 92.17 & 7.83 & 40.42 & 55.70 \\
\hline A31 & 51.25 & 92.16 & 7.84 & 41.03 & 63.98 \\
\hline A 32 & 43.19 & 91.69 & 8.31 & 35.22 & 56.22 \\
\hline A33 & 37.21 & 91.42 & 8.58 & 39.10 & 56.17 \\
\hline A34 & 43.81 & 92.48 & 7.52 & 37.73 & 49.34 \\
\hline A35 & 46.93 & 92.60 & 7.40 & 41.00 & 61.90 \\
\hline A36 & 42.42 & 92.02 & 7.98 & 39.43 & 55.89 \\
\hline A 37 & 36.39 & 88.75 & 11.25 & 38.93 & 57.02 \\
\hline A38 & 41.29 & 90.83 & 9.17 & 37.95 & 62.54 \\
\hline A39 & 37.15 & 89.22 & 10.78 & 37.67 & 56.24 \\
\hline A40 & 27.87 & 92.70 & 7.30 & 40.76 & 59.95 \\
\hline A41 & 26.72 & 88.21 & 11.79 & 32.01 & 46.09 \\
\hline A42 & 45.05 & 92.37 & 7.63 & 38.10 & 56.79 \\
\hline A43 & 57.43 & 91.92 & 8.08 & 38.44 & 58.02 \\
\hline A44 & 45.28 & 92.82 & 7.18 & 36.60 & 49.28 \\
\hline A45 & 55.70 & 90.90 & 9.10 & 37.17 & 53.90 \\
\hline
\end{tabular}




\begin{tabular}{cccccc} 
A46 & 42.18 & 86.44 & 13.56 & 40.08 & 56.80 \\
A47 & 41.16 & 89.58 & 10.42 & 35.11 & 51.29 \\
A48 & 31.34 & 89.12 & 10.88 & 40.83 & 56.45 \\
A49 & 46.27 & 91.33 & 8.67 & 33.73 & 51.25 \\
A50 & 41.27 & 89.46 & 10.54 & 36.87 & 48.26 \\
A51 & 51.23 & 87.09 & 12.91 & 39.51 & 62.18 \\
A52 & 41.67 & 91,35 & 8,65 & 38,18 & 52,07 \\
A53 & 63.02 & 92.58 & 7.42 & 36.11 & 52.57 \\
A54 & 30.46 & 83.82 & 16.18 & 31.54 & 46.72 \\
A55 & 46.55 & 91.07 & 8.93 & 39.02 & 57.51 \\
A56 & 31.68 & 87.06 & 12.94 & 31.36 & 49.23 \\
A57 & 52.47 & 91.86 & 8.14 & 39.09 & 58.16 \\
A58 & 35.46 & 91.23 & 8.77 & 32.37 & 48.37 \\
A59 & 38.87 & 91.01 & 8.99 & 37.92 & 55.47 \\
\hline Mean & 42.03 & 89.34 & 10.66 & 37.12 & 53.70 \\
standard deviation & 8.46 & 3.03 & 3.03 & 3.05 & 4.72 \\
CV $\%)$ & 20.13 & 3.39 & 28.40 & 8.23 & 8.80 \\
\hline
\end{tabular}

$* \mathrm{LD}=$ longitudinal diameter; $\mathrm{TD}=$ transverse diameter.

Table 2. Chemical characteristics of cambuci fruits from 59 accessions of a commercial plantation located in Natividade da Serra-SP, Brazil.

\begin{tabular}{|c|c|c|c|c|c|c|c|}
\hline Access & $\mathrm{pH}$ & $\begin{array}{l}\mathrm{SSC} \\
\left({ }^{\circ} \mathrm{Bx}\right)\end{array}$ & $\begin{array}{c}\text { TA } \\
\left(\mathrm{g} 100 \mathrm{~g}^{-1}\right)\end{array}$ & $\mathrm{SSC} / \mathrm{TA}$ & $\begin{array}{c}\mathrm{AA} \\
\left(\mathrm{mg} 100 \mathrm{~g}^{-1}\right)\end{array}$ & 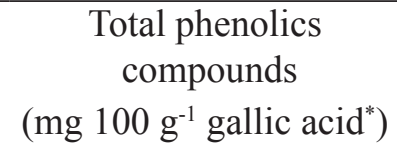 & $\begin{array}{c}\text { DPPH } \\
\left(\mu \mathrm{mol} \mathrm{g}{ }^{-1} \text { Trolox }^{*}\right)\end{array}$ \\
\hline A1 & 2.51 & 8.25 & 1.76 & 4.68 & 83.36 & 508.42 & 37.68 \\
\hline $\mathrm{A} 2$ & 2.57 & 7.20 & 1.50 & 4.80 & 93.67 & 527.94 & 48.64 \\
\hline A3 & 2.47 & 6.10 & 1.67 & 3.66 & 54.02 & 461.17 & 44.08 \\
\hline A4 & 2.45 & 8.05 & 2.32 & 3.47 & 47.11 & 545.89 & 52.57 \\
\hline A5 & 2.83 & 9.80 & 1.62 & 6.06 & 74.47 & 653.41 & 70.96 \\
\hline A6 & 2.60 & 10.05 & 1.58 & 6.38 & 68.00 & 670.57 & 63.02 \\
\hline A7 & 2.45 & 9.15 & 2.90 & 3.16 & 128.57 & 558.69 & 44.21 \\
\hline A8 & 2.60 & 9.20 & 1.77 & 5.21 & 39.75 & 568.38 & 69.46 \\
\hline A9 & 2.43 & 9.15 & 2.38 & 3.84 & 92.79 & 597.77 & 63.85 \\
\hline A10 & 2.66 & 10.20 & 2.18 & 4.67 & 51.42 & 733.18 & 76.37 \\
\hline A11 & 2.47 & 8.95 & 2.16 & 4.15 & 77.78 & 478.49 & 47.37 \\
\hline A12 & 2.41 & 8.70 & 2.14 & 4.07 & 65.14 & 561.94 & 45.99 \\
\hline A13 & 2.55 & 10.40 & 1.65 & 6.29 & 54.34 & 557.19 & 56.23 \\
\hline A14 & 2.59 & 10.55 & 1.64 & 6.45 & 83.83 & 1042.74 & 95.67 \\
\hline A15 & 2.63 & 10.30 & 1.93 & 5.35 & 106.12 & 883.12 & 90.27 \\
\hline A16 & 2.65 & 7.85 & 1.82 & 4.31 & 64.80 & 777.02 & 86.33 \\
\hline A17 & 2.60 & 6.20 & 1.29 & 4.82 & 53.21 & 438.44 & 36.38 \\
\hline A18 & 2.39 & 9.45 & 2.28 & 4.14 & 78.16 & 575.76 & 73.60 \\
\hline A19 & 2.44 & 7.65 & 2.17 & 3.52 & 89.92 & 560.09 & 61.56 \\
\hline $\mathrm{A} 20$ & 2.66 & 11.00 & 1.30 & 8.46 & 78.85 & 741.45 & 72.36 \\
\hline $\mathrm{A} 21$ & 2.45 & 8.20 & 2.46 & 3.34 & 62.87 & 544.20 & 48.82 \\
\hline A22 & 2.41 & 10.10 & 2.40 & 4.22 & 54.73 & 500.42 & 54.31 \\
\hline A23 & 2.50 & 7.10 & 2.18 & 3.26 & 54.01 & 481.68 & 47.47 \\
\hline A24 & 2.57 & 8.20 & 1.87 & 4.39 & 53.02 & 491.80 & 46.09 \\
\hline A 25 & 2.55 & 9.90 & 1.88 & 5.28 & 44.42 & 519.97 & 49.93 \\
\hline A26 & 2.47 & 7.10 & 2.19 & 3.24 & 51.19 & 524.20 & 40.34 \\
\hline A 27 & 2.49 & 8.65 & 1.78 & 4.87 & 92.32 & 585.73 & 95.45 \\
\hline A28 & 2.66 & 8.35 & 1.63 & 5.11 & 92.72 & 691.87 & 45.19 \\
\hline
\end{tabular}




\begin{tabular}{|c|c|c|c|c|c|c|c|}
\hline A29 & 2.45 & 10.40 & 2.42 & 4.30 & 43.99 & 514.72 & 41.60 \\
\hline A 30 & 2.46 & 10.15 & 2.30 & 4.42 & 68.83 & 520.35 & 32.60 \\
\hline A31 & 2.59 & 10.20 & 2.07 & 4.93 & 85.97 & 420.12 & 57.62 \\
\hline A32 & 2.66 & 8.25 & 1.56 & 5.31 & 70.02 & 656.43 & 67.24 \\
\hline A33 & 2.56 & 7.70 & 1.90 & 4.05 & 84.35 & 845.31 & 83.74 \\
\hline A34 & 2.63 & 11.00 & 2.11 & 5.21 & 69.98 & 505.05 & 69.56 \\
\hline A 35 & 2.52 & 8.95 & 1.71 & 5.25 & 91.05 & 365.97 & 62.85 \\
\hline A 36 & 2.54 & 7.40 & 1.76 & 4.22 & 69.70 & 633.03 & 82.69 \\
\hline A37 & 2.54 & 7.15 & 2.05 & 3.48 & 70.89 & 594.81 & 65.14 \\
\hline A38 & 2.58 & 8.55 & 1.41 & 6.09 & 62.59 & 532.47 & 57.37 \\
\hline A39 & 2.40 & 7.10 & 2.40 & 2.96 & 139.38 & 704.93 & 97.97 \\
\hline A40 & 2.55 & 7.75 & 2.26 & 3.43 & 84.15 & 578.33 & 66.41 \\
\hline A41 & 2.65 & 7.80 & 1.65 & 4.72 & 83.59 & 476.68 & 140.15 \\
\hline A42 & 2.60 & 9.00 & 1.57 & 5.73 & 94.03 & 507.45 & 47.15 \\
\hline A43 & 2.42 & 7.70 & 2.11 & 3.66 & 47.24 & 429.44 & 41.05 \\
\hline A44 & 2.51 & 8.50 & 1.63 & 5.22 & 110.73 & 687.24 & 63.09 \\
\hline A45 & 2.42 & 8.60 & 2.21 & 3.90 & 49.58 & 555.63 & 38.88 \\
\hline A46 & 2.46 & 5.10 & 2.15 & 2.37 & 52.03 & 330.50 & 42.12 \\
\hline A47 & 2.52 & 8.40 & 1.68 & 5.00 & 54.99 & 486.68 & 36.71 \\
\hline A48 & 2.49 & 10.65 & 2.42 & 4.41 & 86.21 & 568.35 & 114.56 \\
\hline A49 & 2.53 & 7.85 & 1.57 & 4.99 & 82.50 & 839.34 & 74.29 \\
\hline A 50 & 2.37 & 6.80 & 2.87 & 2.37 & 71.02 & 543.90 & 51.59 \\
\hline A51 & 2.58 & 10.10 & 1.81 & 5.58 & 48.05 & 382.61 & 125.06 \\
\hline A52 & 2.58 & 7.85 & 1.72 & 4.56 & 96.40 & 401.71 & 43.10 \\
\hline A53 & 2.45 & 9.10 & 1.97 & 4.61 & 49.55 & 390.19 & 34.88 \\
\hline A54 & 2.55 & 6.75 & 1.83 & 3.69 & 66.64 & 906.61 & 199.78 \\
\hline A55 & 2.56 & 7.65 & 1.46 & 5.26 & 72.48 & 500.98 & 40.18 \\
\hline A56 & 2.73 & 7.15 & 1.59 & 4.51 & 97.33 & 3526.04 & 131.79 \\
\hline A57 & 2.46 & 10.55 & 2.07 & 5.10 & 33.66 & 394.74 & 29.83 \\
\hline A58 & 2.71 & 9.05 & 1.33 & 6.80 & 31.12 & 356.33 & 100.71 \\
\hline A59 & 2.61 & 8.20 & 1.64 & 5.00 & 98.82 & 498.53 & 32.96 \\
\hline Mean & 2.54 & 8.60 & 1.93 & 4.62 & 72.16 & 617.90 & 65.03 \\
\hline $\begin{array}{l}\text { Standard } \\
\text { deviation }\end{array}$ & 0.09 & 1.35 & 0.37 & 1.10 & 22.36 & 410.73 & 30.99 \\
\hline $\mathrm{CV}(\%)$ & 3.73 & 15.68 & 19.02 & 23.94 & 30.99 & 66.47 & 47.66 \\
\hline
\end{tabular}

$*$ fresh weight. $* * \mathrm{pH}$ value $=$ potential of hydrogen; $\mathrm{SSC}=$ soluble solids content; $\mathrm{TA}=$ titratable acidity; $\mathrm{SSC} / \mathrm{TA}=$ ratio; $\mathrm{AA}=$ ascorbic acid; $\mathrm{TPC}=$ total $\mathrm{phenolic}$ compounds; DPPH= antioxidant capacity measured by DPPH radical sequestration.

Table 3. Correlation matrix between physical and chemical characteristics of 59 cambuci accessions of a commercial plantation located in Natividade da Serra-SP, Brazil.

\begin{tabular}{lccccccccccc}
\hline Variable & Fresh weight & Yield & LD & TD & SSC & TA & SSC/TA & AA & TPC & DPPH & Peel \\
\hline Fresh weight & 1.00 & & & & & & & & & & \\
Yield & 0.42 & 1.00 & & & & & & & & & \\
LD & 0.53 & 0.38 & 1.00 & & & & & & & & \\
TD & 0.56 & 0.37 & $0.75^{*}$ & 1.00 & & & & & & & \\
SSC & 0.16 & 0.26 & 0.06 & 0.12 & 1.00 & & & & & & \\
TA & -0.15 & -0.10 & 0.15 & -0.02 & 0.05 & 1.00 & & & & & \\
SSC/TA & 0.23 & 0.26 & -0.08 & 0.07 & 0.60 & $-0.73^{*}$ & 1.00 & & & & \\
AA & -0.22 & 0.15 & -0.05 & -0.05 & -0.06 & 0.06 & -0.06 & 1.00 & & & \\
TPC & -0.26 & -0.13 & -0.36 & -0.23 & -0.09 & -0.15 & 0.05 & 0.26 & 1.00 & & \\
DPPH & -0.49 & -0.22 & -0.42 & -0.28 & 0.01 & -0.15 & 0.11 & 0.19 & 0.42 & 1.00 & \\
Peel & -0.42 & $-1.00^{*}$ & -0.38 & -0.37 & -0.26 & 0.01 & -0.26 & -0.15 & 0.13 & 0.22 & 1.00
\end{tabular}

$\mathrm{LD}=$ longitudinal diameter $\mathrm{TD}=$ transverse diameter; $\mathrm{SSC}=$ soluble solids content; $\mathrm{TA}=$ titratable acidity; $\mathrm{SSC} / \mathrm{TA}=$ ratio; Peel= peel $\%$; $\mathrm{AA}=$ ascorbic acid; $\mathrm{TPC}=$ total phenolic compounds; $\mathrm{DPPH}=$ antioxidant capacity measured by DPPH radical sequestration. ${ }^{*}$ Significant correlation at $\mathrm{p}<0.05$. 
The physicochemical parameters of fruits greatly varied between accessions. Cambuci crops are not yet technified, so high variability was expected. We highlight the content of soluble solids, which ranged from 5.10 ${ }^{\circ}$ Brix to $11.00^{\circ}$ Brix, and show the versatility and potential of using these fruits in natura and in processed products. The results also strong indicated cambuci as a rich source of ascorbic acid, phenolic bioactive compounds, and with high antioxidant capacity.

We thank the São Paulo Research Foundation (FAPESP) - grant \#2014/12606-3 (research funding), the Coordination of Personal Improvement in Superior Education (CAPES) for awarding the scholarship. We also thank the rural grower from Natividade da Serra-SP, Brazil, Paulo Nakanishi and his family for providing the cambuci fruit. We gratefully acknowledge the cooperation of the Forest Engineer Ivan Suarez da Mota from the Forest Institute during the early stages of this project. Thanks to the Agronomist Engineer Horst Bremer Neto, Ph.D. from the Crop Science Department of the "Luiz de Queiroz" College of Agriculture - ESALQ/USP for the suggestions about the experimental design.

\section{References}

AL-DUAIS, M.; MÜLLER, L.; BÖHM, V.; JETSCHKE, G. Antioxidant capacity and total phenolics of Cyphostemma digitatum before and after processing: use of different assays. European of Food Research and Technology, Heidelberg, v.228, n.5, p.813-821, 2009.

AMBRIZ-PÉREZ, D.L.; LEYVA-LÓPEZ, N., GUTIERREZ-GRIJALVA, E.P., HEREDIA, J.B. Phenolic compounds: Natural alternative in inflammation treatment. A Review. Cogent Food \& Agriculture, Seville, v.2, n.1, p.1131412, 2016.

AOAC - Association of Official Analytical Chemists. Official methods of analysis of AOAC international. $19^{\text {th }}$ ed. Gaithersburg, 2012. 1015p.

BIANCHINI, F.G.; BALBI, R.V.; PIO, R.; SILVA, D.F.; PASQUAL, M.; VILAS BOAS, E.V.B. Caracterização morfológica e química dos frutos de cambucizeiro. Bragantia, Campinas, v.75, p.10-18, 2016.

BRASIL, A.S.; SIGARINI, K.D.S.; PARDINHO, F.C.; FARIA, R.A.P.G.; SIQUEIRA, N.F.; PICANÇO, M. Avaliação da qualidade físico-química de polpas de fruta congeladas comercializadas na cidade de Cuiabá-MT. Revista Brasileira de Fruticultura, Jaboticabal, v.38, n.1, p.167-175, 2016.

COMIOTTO, A.; FACHINELLO, J.C.; HOFFMANN,
A.; PORTELLA MACHADO, N.; GALARÇA, S.P.; BETEMPS, D.L. Vigor, floração, produção e qualidade de pêssegos 'Chimarrita' e 'Maciel' em função de diferentes porta-enxertos. Ciência Rural, Santa Maria, v.42, n.5, p.788-794, 2012.

DONADO-PESTANA, C.M.; BELCHIOR T.; FESTUCCIA W.T.; GENOVESE M.I. Phenolic compounds from cambuci (Campomanesia phaea O.Berg) fruit attenuate glucose intolerance and adipose tissue inflammation induced by a high-fat, high-sucrose diet. Food Research International, Oxford, v.69, p.170178, 2015.

GENOVESE, M.I.; PINTO, M.S.; GONÇALVES, A.E.S.S.; LAJOLO, F.M. Bioactive compounds and antioxidant capacity of exotic fruits and commercial frozen pulps from Brazil. Revista de Agroquímica y Tecnologia de Alimentos, Valência, v.14, n.3, p.207214, 2008.

INSTITUTO AUÁ. Empreendimentos socioambiental. Rota do Cambuci. Osasco, 2017. Disponível em: $\leq \mathrm{http}: / /$ www.aua.org.br/>. Acesso em: 15 jul. 2017.

LADANIYA, M.S. Citrus fruit: biology, technology and evaluation. San Diego: Elsevier, 2008. 576p.

LIMA, J.S.S.; CASTRO, J.M.C.; SABINO, L.B.S.; LIMA, A.C.S.; TORRES, L.B.V. Physicochemical properties of Gabiroba (campomanesia lineatifolia) and Myrtle (blepharocalyx salicifolius) native to the mountainous region of Ibiapaba-CE, Brazil. Revista Caatinga, Mossoró, v.29, n.3, p.753-757, 2016.

LORENZI, H.; SARTORI, S.F.; BACHER, L.B.; LACERDA, M.T.C. Frutas brasileiras e exóticas cultivadas. Nova Odessa: Instituto Plantarum, 2006. $640 \mathrm{p}$.

LUTZ, M.; HERNÁNDEZ, J.; HENRÍQUEZ, C. Phenolic content and antioxidant capacity in fresh and dry fruits and vegetables grown in Chile. CyTA-Journal of Food, Abingdon, v.13, n.4, p.541-547, 2015.

MEDEIROS, S.A.F.; YAMANISHI, O.K.; PEIXOTO, J.R.; PIRES, M.C.; JUNQUEIRA, N.T.V.; RIBEIRO J.G.B.L. Caracterização físico-química de progênies de maracujá-roxo e maracujá-azedo cultivados no Distrito Federal. Revista Brasileira de Fruticultura, Jaboticabal, v.31, n.2, p.492-499, 2009.

RUFINO, M.S.M.; ALVES, R.E.; BRITO, E.S.; PÉREZJIMÉNEZ, J.; SAURA-CALIXTOF.; MANCINI-FILHO

J. Bioactive compounds and antioxidant capacities of 18 non-traditional tropical fruits from Brazil. Food Chemistry, Barking, v.121, n.4, p.996-1002, 2010. 
SANCHES AZEVEDO, M.C.; SILVA, R.R.E.; JACOMINO, A.P.; GENOVESE, M.I. Physicochemical variability of cambuci fruit (Campomanesia phaea) from the same orchard, from different locations and at different ripening stages. Journal of the Science of Food and Agriculture, London, v.97, n.2, p.526-535, 2017.

SILVA, I.G.; CORREIA, A.D.F.K.; BIGARAN, J.T.; BAPTISTA, C.P.; DO CARMO, L.F.; SPOTO, M.H.F. Estudo de caracterização do fruto cambuci [Campomanesia phaea (O.Berg.) Landrum] e sua aplicação no processamento de geléia. Boletim do Centro de Pesquisa de Processamento de Alimentos, Curitiba, v.30, n.1, p.83-90, 2012.

SILVA, L.M.R.; FIGUEIREDO, E.A.T.; RICARDO, N.M.P.S.; VIEIRA, I.G.P.; FIGUEIREDO, R.W.; BRASIL, I.M.; GOMES, C.L. Quantification of bioactive compounds in pulps and by-products of tropical fruits from Brazil. Food Chemistry, Barking, v.143, p.398404, 2014.

SOUNIS, E. Bioestatística: princípios fundamentais, metodologia estatística, aplicação às ciências biológicas. 2.ed. São Paulo: McGraw-Hill, 1975. 230p.

STATSOFT. Statistica (data analysis software system). Version 7.0. 2015. Disponível em: $\leq$ http://www.statsoft. com>. Acesso em: 12 mar. 2015.

STROHECKER, R.; HENNING, H.M. Analisis de vitaminas: métodos comprobados. Madrid: Paz Montalvo, 1967. 428p.
TACO. Tabela brasileira de composição de alimentos. 4.ed. Campinas: NEPA-UNICAMP, 2011.161p. Disponível em: <http://www.unicamp.br/ nepa/taco/contar/taco 4 edicao ampliada e revisada. pdf?arquivo $=$ taco 4 versao ampliada e revisada.pdf $>$. Acesso em: 10 out. 2016.

VALLILO, M.I.; GARBELOTTI, M.L.; OLIVEIRA, E.D.; LAMARDO, L.C.A. Características físicas e químicas dos frutos do cambucizeiro (Campomanesia phaea). Revista Brasileira de Fruticultura, Jaboticabal, v.27, n.2, p.241-244, 2005.

VASCO, C.; RUALES, J.; KAMAL-ELDIN, A. Total phenolic compounds and antioxidant capacities of major fruits from Ecuador. Food Chemistry, Barking, v.111, n.4, p.816-823, 2008.

WOISKY, R.G.; SALATINO, A. Analysis of propolis: some parameters and procedure for chemical quality control. Journal of Apicultural Research, Cardiff, v.37, p.99-105, 1998.

WU, D.; SUN, D.W. Colour measurements by computer vision for food quality control-A review. Trends in Food Science \& Technology, Cambridge, v.29, n.1, p.520, 2013. 